Observations of Variable Stars in I 888. - Mr. Sawyer publishes the results of his observations of variable stars made in 1888, in Gould's Astronomical fournal, No. 190. Amongst the principal of these were U Orionis (Gore's variable), observed at maximum 1888 December 26; Mira Ceti at maximum 1887 November ro; W. Cygni at minimum r889 January I, since when it has brightened fast. $\rho$ Persei was considered as having been at minimum, 1888 November $7 ; \epsilon$ Aurigæ about 1889 January 15. R Scuti seems to have been just three weeks in advance of the ephemeris in NATURE; R Lyræ and U Monncerotis corresponded to the predicted times pretty closely. $R$ Virginis also was estimated to be at maximum only one day later than given by the ephemeris ; $g$ Herculis was recorded as at maximum 1888 June 3 and September 11 , and at minimum July 18.

\title{
ASTRONOMICAL PHENOMENA FOR THE WEEK 1889 APRIL 14-20.
}

(FOR the reckoning of time the civil day, commencing at Greenwich mean midnight, counting the hours on to 24 , is here employed.)

\section{At Greenzich on April 14}

Sin rises, 5 h. $7 \mathrm{~m}$.; souths, I $2 \mathrm{~h}$. Om. $\mathrm{II}^{\circ} 5 \mathrm{~s}$.; sets, $18 \mathrm{~h} .53 \mathrm{~m}$. : right asc. on meridian, Ih. $31^{\circ} 6 \mathrm{~m}$.; decl. $9^{\circ} 35^{\prime} \mathrm{N}$. Sidereal Time at Sunset, $8 \mathrm{~h} .25 \mathrm{~m}$.

Moon (Full on April 15, 22h.) rises, 17h. 3m. ; souths, 23h. $20 \mathrm{~m}$. ; sets, 5 h. $2 \mathrm{Im}^{*}{ }^{*}$ : right asc. on meridian, I2h. $5^{\circ}{ }^{\circ} 9 \mathrm{~m}$.; decl. $0^{\circ} 14^{\prime} \mathrm{S}$.

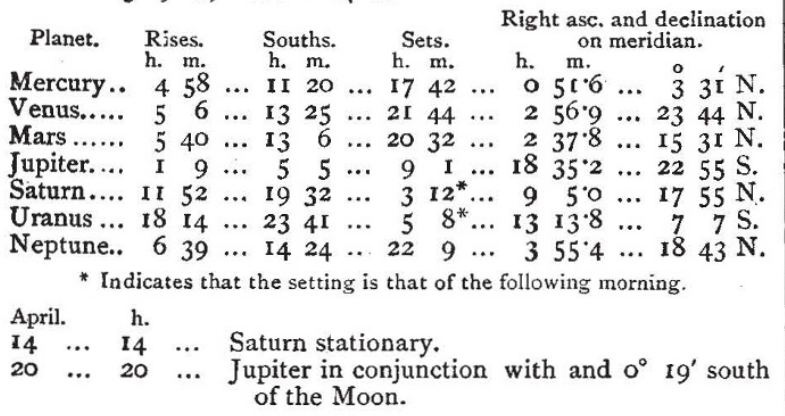

Variable Stars.

Star.

U Cephei

Algol 3 I.0 ... $4032 \mathrm{~N}$...Apr. 16,3 I4 $m$

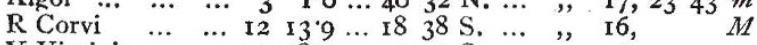

$\begin{array}{llllllllllllll}\mathrm{Y} & \text { Virginis } & \ldots & \ldots & \mathbf{1} 2 & 28 \cdot 1 & \ldots & 3 & 49 & \mathrm{~S} . & \ldots & ,, & \mathbf{1} 7, & m\end{array}$

$\begin{array}{lllllllllllllll}\delta \text { Libræ } & \ldots & \ldots & \text { I4 } & 55: 1 & \ldots & 8 & 5 & \mathrm{~S} . & \ldots & \ldots & \text { I6, } & \text { I } & 8 & \mathrm{~m}\end{array}$

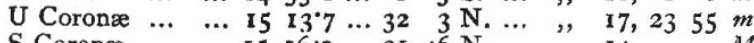

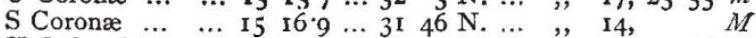

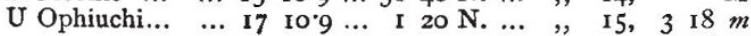

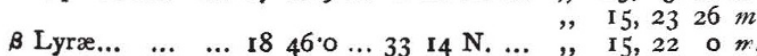

$\begin{array}{lllll} & 15,22 & 0 & m \\ & & 19, & 30 & M\end{array}$

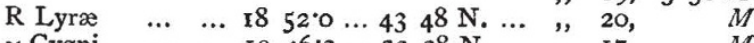

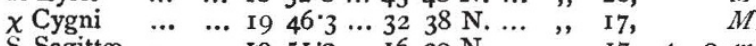

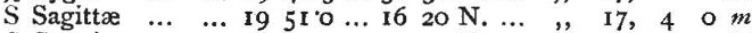

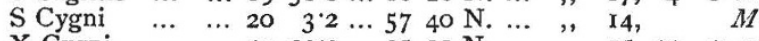

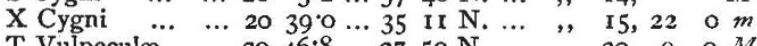

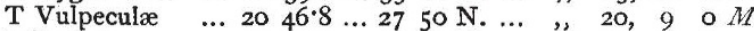

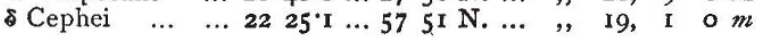

$M$ signifies maximum ; $m$ minimum ; $m_{2}$ secondary minimum.

\section{Meteor-Showers. \\ R.A. Decl.}

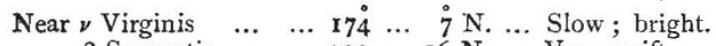

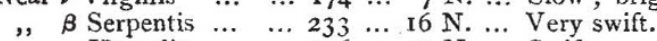

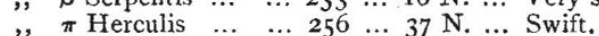

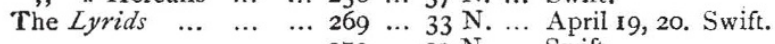

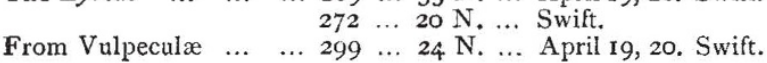

\section{GEOGRAPHICAL NOTES.}

ThE Founder's Medal of the Royal Geographical Society has been awarded to Mr. A. D. Carey, of the India Civil Service, for his remarkable journey in Central Asia, at his own risk and expense, during which be travelied over a distance of $475^{\circ}$ miles, through regions which have never before been visited by an Englishman, and very rarely by any European. The Patron's Medal has been awarded to Dr. G. Radde, Director of the Natural History Museum, Tiflis, for a life devoted to the promotion of scientific geography, as a traveller, observer, and author. The Murchison Grant has been given to Mr. F. S. Arnot, towards providing and conveying a suitable present to the Chief Chitambo, of Ilala, as a recompense for his services in connection with the removal of the body and personal property of Dr. Livingstone in 1872 . Mr. Arnot also receives the Cuthbert Peek Grant, in recognition of the interest and value of his seven years' travels in Central Africa. The Back Premium has been awarded to Mr. F. C. Selous, in acknowledgment of the geographical work accomplished by him in his recent journey in Mashona Land and north of the Zambesi ; and the Gill Memorial to Mr. M. J. Ogle, of the Indian Survey Department, in recognition of his excellent survey work in Eastern Assam, in Manipur, and in Northern and Western Burma. The three new honorary corresponding members are Captain Dutton, of the U.S. Survey ; M. Maunoir, secretary of the Paris Geographical Society ; and Dr. Ballivian, a Bolivian geographer. Sir Mountstuart Grant Duff will succeed General Richard Strachey as President.

ON Monday night Mr. Harold W. Topham read to the Royal Geographical Society an account of his visit last summer to the Glaciers of Alaska and Mount St. Elias. Speaking of Glacier Bay, near Sitka, Mr. Topham said that into it many large glaciers descend, only one of which, the Muir, has been explored. It is thirty miles long, and its breadth, where it runs out into the sea, is one mile. It is decreasing very rapidly, so rapidly, indeed, that the sailors assert that they can, year by year, distinguish the difference in its size. The height of the ice wall at the foot of the glacier, where it is washed by the sea, was 319 feet in 1886, whilst last year it was 266 feet, a decrease of 53 feet. A cairn which had been erected to ascertain the rate of motion of the glacier, was found almost overthrown into a crevasse. Mr. Topham speaks of the magnificence of the mountain range stretching from Cross Sound to Yakatat. The peaks reach up I6,000 feet, the whole of which height is at once presented to the view. Their bases are washed by the sea, into which their glaciers descend. Many of these glaciers are singularly free from moraine. They are exceedingly steep, and are broken up into innumerable ice falls. The St. Elias Alps, from Cross Sound to Fairweather, run close to the sea. They then curve inland, and sweep round Yakatat Bay at a distance of about thirty miles from the water. There are many fine peaks in the range, and the eye wanders on from summit to summit till it rests upon the finest of all, Mount St. Elias, at the far north-west of the range. Lieutenant Allen stated this peak to be 19,500 feet high. It is the highest mountain in North America. To the north and west of Yakatat Bay all is ice. It is a vast plain of ice, stretching back sixty miles or more, and running eighty miles along the coast. At a place fifty miles up the glacier from the bay, the party found they were only 650 feet above the sea. This gives a fall of only 13 feet to the mile. The rate of progress, therefore, of the ice, must be very small, and this is proved by the quantity of scrub and trees which grow upon the terminal moraine upon the top of the ice. The moraine is several miles broad, and is covered with brush of alder and willow and spruce. The party proceeded by boat from Yakatat to opposite Mount St. Elias. They proceed up the Yahtsétah River. Seven miles from the sea, the river issues from beneath the ice, and it brings with it such a quantity! of dirt, that the water is of a greyish-white. The river, where it issues from the ice, is about 50 feet broad, but it divides and subdivides to such an extent that at its mouth it is about seven miles in width. The west bank is composed entirely of ice. Where the river issues from under the ice, the latter is 500 feet thick, and possesses a moraine several miles wide, the last mile of which, the one nearest the edge of the glacier, is covered with thick brush. Through this brush they had some difficulty in forcing their way to the open glacier beyond. The best way of describing the moraines upon the Malaspina Glacier is to liken the 
surface of the ice to a very choppy sea, on to which has rained innumerable stones and rocks. The depressions are often 100 feet deep. On this moraine were found shale and slate granite quartz, with sulphates and pyrites and copper. After several ineffectual attempts Mr. Topham and his companions decided to ascend St. Elias on the south-west side, west of the Chaix Hills. The party ultimately, from their camp 1500 feet high, reached the brink of the crater, 7600 feet above sealevel and 5000 above the Tyndall glacier; another six hours found them at a height of II,46I feet. They were then on the northern and upper rim of the crater, and judged the summit to be another seven or eight thousand feet above. The crater is full of ice, and upon its precipitous cliffs are a number of overhanging glaciers, splashed, as it were, upon the rocks and unattached from the snow-fields above. This is characteristic of a number of the glaciers in the neighbourhood. There they are -right on the rocks, with yawning crevices upon them broken up and ready to topple over upon you. Perhaps in a few years they will have melted entirely away. Everything, Mr. Topham states, around St. Elias bears evidence to the conclusion that the long period of ice through which the land has been passing is now coming to an end; a conclusion which is certainly rash. Mr. Topham gave a detailed description of the panorama to be seen from the highest point reached. There is, he states, vegetation upon the south-east slopes of the hills to a height of 1500 feet above the glacier. The greatest height at which he found vegetation, exclusive of lichens, was 4500 feet above the sea, but the place was exposed to the full glare of the sun, and no other vegetation was found for an interval of 1500 feet below. A characteristic of the Alaskan glaciers is the curious way in which small isolated bits of moraine show up here and there above the ice. For example, you may walk down the centre of the Tyndall upon white ice without seeing more than a few stones to suggest the existence of a moraine, and suddenly you will come upon an island of débris, disconnected from any regular moraine. It springs from nowhere, is quite isolated, and appears to have no reason for being there.

\section{BIOLOGICAL NOTES.}

The Rattle of the Rattlesnake. - The habit of slough. ing is common to all serpents : a short time before the removal of the old skin takes place, the new epiderm makes its appearance beneath the old. The mode of growth of the new and the removal of the old is the same in all snakes, with the exception that, in those with a ratile, that portion of the slough that covers the tip of the tail is retained to form one of the rings of the rattle. The attachment is simply mechanical; the rings are merely the sloughs off the end of the tail. The terminal bone of the tail is formed of vertebræ that have coalesced and changed in great measure their shape ; in the different species the number of vertebræ included in this bone varies considerably, and sometimes it varies in individuals of the same species. With the purpose of indicating the manner of growth of the rattle, and as far as possible determining its origin, Mr. S. Garman has followed up its appearance in several species, full details of which, with figures, have been lately published. In the very young rattlesnake, while the vertebre are still separate, there is no rattle, but about a week after birth a well-marked button is seen; with the first slough the first ring is set free, the button being pushed forward, and a third button is gradually perfected. In time the traces of the vertebræ in the terminal bone are almost oblitesated ; the bone becomes thickened, pushed forward at its edges, and otherwise enlarged. In a full-grown rattlesnake the hinder seven of the rings belong to the period of the snake's most rapid growth-they form the "tapering rattle" formerly used in classification of the species; while four of the rings and the button are formed while the gain in size was less rapid, and form the "parallelogrammic rattle" of the old classifiers. Many serpents besides those possessed of a "crepitaculum" are addicted to making a rattling noise by vibrations of the end of their tails. In illustration of the extent to which the tail has been modified in different cases, Mr. Garman figures the tails of several species, among others that of Ancistrodon contortrix, Lin., the copperhead of the United States. The tip of its tail is directed downwards as well as a little backwards; most often the button has one or two swellings in a degree resembling those on a ring of the rattle. A living specimen of this snake, kept for a year or more, would take to rattling on the floor whenever it was irritated ; the sound was made by the terminal inch of the tail, this part being swung from side to side in the segment of a circle, so that the tip might strike downward. The result was a tolerable imitation of the sound made by a small rattlesnake.-(Bulletin Museum Comp. Anatomy, vol. xiii. No. Io, August 1888.)

A New Species of Laminaria.-The discovery in the Mediterranean Sea, midway between Marseilles and Algiers, of a Laminaria, not only new to the shores of Europe, but an addition to the group-one, too, neither small in size nor obscure in its characteristics-is a very interesting fact for botanists. Laminaria rodriguezii has been described by Dr. Ed. Bornet in a recent number of the Proceedings of the Botanical Society of France. It was taken by M. J. Rodriguez a few miles sonth of Port Mahon, on a rocky bottom, in a depth of from 125 to 150 metres. It was also taken on the east and north coasts of Minorca. It appeared to be abundant in the first-mentioned of these localities. The fronds grow to a height of 2 metres. In general aspect, consistence, and colour this new species somewhat resembles $L$. saccharina, but it cannot be for a moment confounded with this well-known form. It is attached to the stones 'upon which it grows by a series of little root-like processes, which emanate from stolons running over the surfaces of the stones. From these stolons the young fronds arise, and in specimens with adult fronds, a whole colony of small fronds will be found springing from the stolons. Lam. bongardiana and $L$. longipes of Kamchatka, L. japonica from Japan, and L. sinclairi from California, are the only known species, with simple fronds, which possess these rooting stolons, but none of these can be confounded with the present new form. Of the five species of Laminariaceæ which have been from time to time recorded as occurring in the Mediterranean, this is the only one that is without any doubt a native. Phyllaria reniformis may possibly be indigenous, but $P /$. purpurascens, Lam. saccharina, and Sac. bulbosa are almost certainly waifs that have been only met with in the neighbourhood of ports. The Lam. saccharina, Ardissone, found growing at Syracuse, in Sicily, proves, however, to be Bornet's new species, which is the sole representative on the Atlantic sea-board of the Pacific Ocean forms above referred to. -(Bull. de la Soc. Bot. de France, tome xxxv. pl. 5.)

The Envllopes in Nostocace e.-M. Maurice Gomont has printed a brief abstract of his researches on the investing envelopes of the filamentous Nostocs. The thallus in these consists of the simple row of cells, the trichome, and the protective envelope, more or less marked (the gaine); when the hormogones are dispersed, this latter disappears. In a 33 to a 5o per cent. solution of chromic acid, the gaine becomes swollen and dissolves, leaving only a tube-like pellicle ; next the protoplasm of the trichome cells becomes greatly changed, leaving the cell-walls clearly defined. These consist of an external layer, seemingly intermediate between the membrane met with in the hyphr of Fungi and the cuticle of the higher plants; it has a remarkable power of resisting the action of acids : in a 33 per cent. solution of chromic acid or in concentrated sulphuric acid, it remains unchanged for a space of twenty-four hours; it is insoluble in hydrochloric or acetic acids, or in caustic potash it is dissolved in a 50 per cent. solution of chromic acid, but only after several hours; with aniline or fuchsine it assumes a brighter hue than ordinary cuticle. The interior layer gives the reactions of cellulose. The chemcal properties of the gaine prove it to be a true cuticle. -(Fournal de Botanique for I888.)

\section{THE SCOTTISH METEOROLOGICAL SOCIETY.}

$A^{\mathrm{T}}$ the half-yearly meeting of the Society, held on Monday, April I, it was stated in the Report of the Council that new stations had recently been added in the Newington District of Edinburgh, and in the Botanic Garden, these additions to the observing staff being regarded with much satisfaction, particularly in view of the facilities which a somewhat thickly planted series of stations in Midlothian offer, in the observation of the physical data required in investigating the various meteorological gradients, as proposed by the late Mr. T. Stevenson. Dr. Archibald Geikie, Prof. Crum Brown, and Prof. Bayley Balfour were elected Members of Council.

The inspection of the fishery barometers of the Meteorological Council at fifty-four of the fishing ports on the Scottish coasts has now been completed by Mr. Dickson, who gave much 